\title{
Nano- and micro-fiber combined scaffolds: A new architecture for bone tissue engineering
}

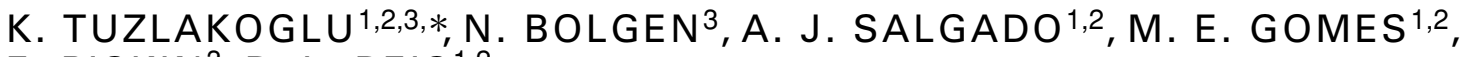 \\ E. PISKIN ${ }^{3}$, R. L. REIS ${ }^{1,2}$ \\ ${ }^{1}$ 3B's Research Group-Biomaterials, Biodegradables and Biomimetics, Univ. Minho, \\ Campus de Gualtar, 4710-057 Braga, Portugal \\ ${ }^{2}$ Department of Polymer Engineering, University of Minho, Campus de Azurém, 4800-058 \\ Guimarães, Portugal \\ ${ }^{3}$ Hacettepe Univ., Chem. Eng. Dept. and Bioeng. Div. and TÜBITAK-Biyomedtek: Center for \\ Biomedical Technologies, Beytepe, 06532, Ankara, Turkey \\ E-mail:kadriye@dep.uminho.pt
}

One possible interesting way of designing a scaffold for bone tissue engineering is to base it on trying to mimic the biophysical structure of natural extracellular matrix (ECM). This work was developed in order to produce scaffolds for supporting bone cells. Nano and micro fiber combined scaffolds were originally produced from starch based biomaterials by means of a fiber bonding and a electrospinning, two step methodology. The cell culture studies with SaOs-2 human osteoblast-like cell line and rat bone marrow stromal cells demonstrated that presence of nanofibers influenced cell shape and cytoskeletal organization of the cells on the nano/micro combined scaffolds. Moreover, cell viability and Alkaline Phosphatase (ALP) activity for both cell types was found to be higher in nano/micro combined scaffolds than in control scaffolds based on fiber meshes without nanofibers.

Consequently, the developed structures are believed have a great potential on the 3D organization and guidance of cells that is provided for engineering of 3-dimensional bone tissues.

(C) 2005 Springer Science + Business Media, Inc.

\section{Introduction}

Bone tissue engineering has become a rapidly expanding research area since it offers a new and promising approach for bone repair and regeneration. Several requirements have been considered for engineering bone, including choosing a cell type that matures/differentiates into bone cells with the proper form and phenotype, regulating the growth factors and designing a so-called ideal scaffold [1]. The requirements for the design and production of an ideal scaffold are also very complex and not yet fully understood. An ideal scaffold must be biocompatible both in bulk and degraded form, exhibit a porous, interconnected, and permeable structure to permit the ingress of cells and nutrients, and should exhibit the appropriate surface structure and chemistry for cell adhesion and proliferation. The processing techniques used to obtain polymeric scaffolds include solvent casting and particulate leaching, gas foaming, freeze drying, rapid prototyping, thermally induce phase separating, fiber bonding, melt molding and electrospinning, as reviewed elsewhere [2]. Several techniques aim to produce a scaffold which can mimic in some way the architecture of the natural extracellular matrix (ECM).

Natural extracellular matrix (ECM) is composed of various protein fibrils and fibers interwoven within a hydrated network of glycosaminoglycan chains [3]. This network structure serves as a scaffold which can support tensile and compressive stresses by the fibrils and hydrated networks. Besides providing an appropriate microenvironment for cells, ECM is responsible for transmitting signals to cell membrane receptors that reach nucleus via intracellular signaling cascades. Therefore, the fibrillar and porous structure of ECM have a great influence on cell functionality, mainly on cell adhesion and migration.

In last few years, the electrospinning processes have attracted a great deal of attention as a way to try to mimic the structure of natural ECM by means of producing fibers down to $3 \mathrm{~nm}$ [4]. This process is based on the generation of an electrical field between a polymeric solution (or a polymer melt) placed in a capillary tube with a pipette or needle of small diameter and a metal collector. When the electrical field reaches its critical value, repulsive electrostatic force overcomes the 
surface tension of the polymeric solution and a charged jet is produced. This charged polymeric jet then undergoes a stretching process which is accompanied by the rapid solvent evaporation and results the formation of long and thin fibers [5]. Electrospinning has been used to fabricate nanofibrous structures from a number of both natural synthetic polymers, such as collagen [6], chitosan [7] chitin [8], silk fibroin [9]) and polyethyleneoxide [10], poly(DL-lactide-co-glycolide) [11], poly(L-lactide) [12], and polycaprolactone [13], among many others. The produced nanofibrous polymeric networks have been proposed for engineering of many different tissues. For instance, Li et al. [14] reported that electrospun poly( $\varepsilon$-caprolactone) membranes could promote chondrocyte proliferation and provide maintenance of chondrogenic phenotype. In another study, polyurethane and gelatin have been used to design a mesoscopically ordered structure for using as an artificial graft [15]. Recently, it has been shown that nanofibrous PCL mats could be used as a scaffold to support differentiation of human mesenchymal stem cell cultured in specific differentiation media [16]. Silk fibroin based nanofibrous matrices have also been tested with human bone marrow stromal cells and proposed as a scaffold for bone tissue engineering [17].

Though there are many studies that have been proposing nanofibrous polymeric mats for tissue engineering, they have a limitation for 3D applications due to their pore size which is smaller than a cellular diameter and can not allow cell migration within the structure. Furthermore, the small size of the fibers tends not to maximize the points of cell attachment which is a negative effect on the expression of several factors and on cell spreading and differentiation.

In the present study, we have developed a novel structure which combines polymeric micro and nanofibers in the same construct that is aimed to serve as a scaffold and mimic the physical structure of ECM for bone tissue regeneration, but simultaneously still providing the macro support that cells do require.

\section{Materials and methods}

\subsection{Materials}

Starch-based scaffolds with a $70 \%$ porosity were prepared from a blend of starch/poycaprolactone (SPCL) $(30 / 70 \mathrm{wt} \%)$ by a fiber bonding process as described elsewhere [18]. All the reagents used were analytical grade unless specified otherwise.

\subsection{Electrospinning process}

Electrospinning was used to obtain nanofibers onto SPCL fiber mesh scaffolds. The aim was to impregnate, as much as possible, the micro-fiber scaffolds with electrospun nanofibers. The solution used in the electrospinning experiments was prepared by dissolving $1 \mathrm{~g}$ of SPCL in $7 \mathrm{ml}$ chloroform. After dissolution was completed, $3 \mathrm{ml}$ of dimethylformamide (DMF) which has a high dielectric constant was added to the solution to enhance electrospinning of the solution.
The polymer solution was then electrospun to the both side of the SPCL fiber mesh scaffolds. Briefly, a polymer solution was placed in a simple capillary glass tube vertically. A special designed collector was used to move samples through the electrospun polymeric jets. A $15 \mathrm{kV}$ voltage was provided by a high power supply at a distance of $10 \mathrm{~cm}$ between a collector and a capillary tube for $10 \mathrm{~s}$.

\subsubsection{Morphological analysis}

The developed structures were analyzed by optical microscopy (Olympus, MIC-D). To observe more detail in morphology of the nanofibers on the scaffolds, a scanning electron microscope (SEM) (Leica Cambridge S360 microscope) was also used.

\subsection{Cell culture}

The developed structures were tested with two different cell type, a human osteoblast-like osteosarcoma SaOs-2 cell line and rat bone marrow stromal cells. In both experiment sets SPCL fiber mesh scaffolds without electrospun nanofibers were used as controls.

In the cell culture experiments with a human osteoblast-like SaOs-2 cell line, cells were seeded onto the scaffold using a density of $3 \times 10^{5}$ cells/scaffolds and allowed to grow for two weeks, with medium (DMEM low glucose supplemented with $10 \%$ Foetal Bovine Serum, $1 \%$ antibiotics/antimicotics changes every 2 days.

Rat bone marrow stromal cells (RBMSC) were obtained from the femoras and tibias of 4 weeksold male Wistar rats (Charles River, Spain) as described elsewhere [19]. Briefly, femurs and tibias were aseptically excised, cleaned of soft tissue, and washed in $\alpha$-MEM (Life Technologies, Grand Island, NY) containing 10 times more amount of normal antibiotics concentration in order to avoid contamination during the harvest. Then, the epiphyses were cut off, and the diaphyses flushed with $5 \mathrm{ml}$ of complete medium [ $\alpha$-MEM (minimal essential medium); Eagle, Sigma, St. Louis, MO], supplemented with $10 \%$ FBS (foetal bovine serum; Biochrome), $50 \mu \mathrm{g} / \mathrm{mL}$ ascorbic acid (Sigma), $50 \mu \mathrm{g} / \mathrm{mL}$ gentamycin, $100 \mu \mathrm{g} / \mathrm{mL}$ ampicillin, $0.3 \mu \mathrm{g} / \mathrm{mL}$ fungizone, $10 \mathrm{mM} \beta$-glycerophosphate (Sigma), and $10^{-8} \mathrm{M} \mathrm{dex}-$ amethasone (Sigma)]. Cells were cultured at $37{ }^{\circ} \mathrm{C}$ in a humidified atmosphere containing $5 \%$ of $\mathrm{CO}_{2}$.

The confluent cell monolayers were detached using trypsin/EDTA (0.25\% tyripsin/0.02\% EDTA, Sigma) and resuspended in complete medium. A $50 \mu \mathrm{l}$ of cell suspension containing $3 \times 10^{5}$ cells were pippeted onto the each scaffold. Cell/scaffold constructs were incubated at $37^{\circ} \mathrm{C}$ for $2 \mathrm{~h}$ to allow RBMSC to diffuse into and adhere to the scaffolds before adding $1 \mathrm{ml}$ of culture medium to each well. The cells on the scaffolds were then allowed to grown for 2 weeks at $37^{\circ} \mathrm{C}$ in a humidified atmosphere containing $5 \%$ of $\mathrm{CO}_{2}$ with medium changes every 2-3 days. 


\subsubsection{Morphological analysis}

After 7 and 14 days of culture, cell/scaffold constructs were fixed in $2.5 \%$ glutaraldehyde, dehydrated through graded series of ethanol and dried. The samples were mounted onto brass stubs, sputter coated with cold and analyzed under a Scanning Electron Microscope (SEM) at an accelerating voltage $15 \mathrm{kV}$.

\subsubsection{Cell proliferation assay}

After 7 and 14 days of culture, cell viability was assessed by using Cell Titer $96^{\circledR}$ Aqueous One Solution Cell proliferation Assay kit (Promega, USA). This test is based on the bioreduction of the substrate, (3-(4,5dimethylthiazol-2-yl)-5-(3-carboxymethoxyphenyl)2(4-sulfophenyl)-2H tetrazolium) (MTS), into a brown formazan product by NADPH or NADP produced by dehydrogenase enzymes in metabolically active cells. For this assay, culture medium was removed, samples were washed with PBS before the addition of serum free medium plus Cell Titer $96{ }^{\circledR}$ Aqueous One Solution (5/1 ratio). The samples were then incubated for three hours at $37{ }^{\circ} \mathrm{C}$ in a humidified atmosphere containing $5 \%$ of $\mathrm{CO}_{2}$. A $100 \mu \mathrm{l}$ of incubated medium was transferred to 96-well plate culture plate and the optical density was read at $490 \mathrm{~nm}$ in a micro-plate reader (Synergy HT, Bio-tek).

\subsubsection{Alkaline phosphatase (ALP) activity}

Alkaline phosphatase (ALP) activity from the scaffolds/ cells constructs was quantified by the specific conversion of p-nitrophenyl phosphate (pNPP) into pnitrophenol (pNP). The enzyme reaction was carried out at $37^{\circ} \mathrm{C}$ for $1 \mathrm{~h}$ and then stopped by a solution containing $2 \mathrm{M} \mathrm{NaOH}$ and $0.2 \mathrm{mM}$ EDTA in distilled water. The absorbance of p-nitrophenol formed was determined at $405 \mathrm{~nm}$ with a reference filter at $620 \mathrm{~nm}$. A standard curve was made using pNP values ranging from 0 to $600 \mu \mathrm{mol} / \mathrm{ml}$. The results were expressed as $\mu \mathrm{mol}$ of $\mathrm{pNP}$ produced $/ \mathrm{ml} / \mathrm{h}$. Please note that ALP activity was determined in weekly collected supernatant and lysed cell for SAOS-2 and RBMSC, respectively.

\section{Results \& discussion}

\subsection{Nano- and micro fiber combined scaffolds}

Fig. 1(a) presents the images of the newly designed combined nano/micro fiber structures. As it can be seen, nanofibers could be randomly electrospun on the microfibers and they present the structure that looks like a nanobridge between the microfibers which is very similar to the architecture of ECM [20]. The average diameter of produced SPCL nanofiber was measured to be around 400nm (Fig. 1(b)). Moreover, nanofibers presented a fine morphology without presence of beads which is refered as a common problem of electropsun fibers [4]. These results also confirmed that the processing parameters were successfully optimized in order to produce fine nanofibers from SPCL.
A)

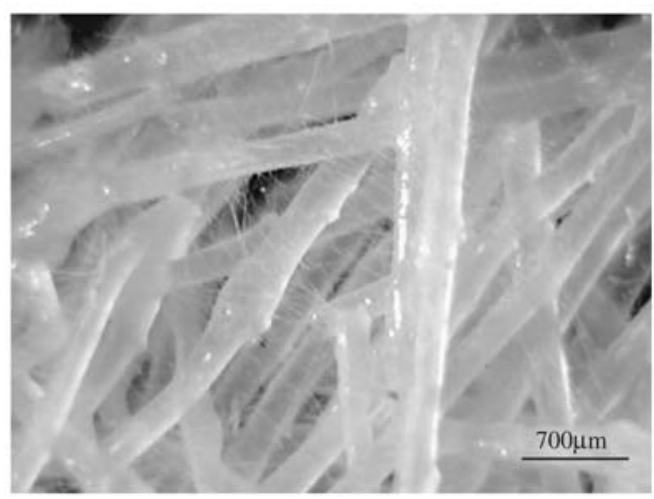

B)

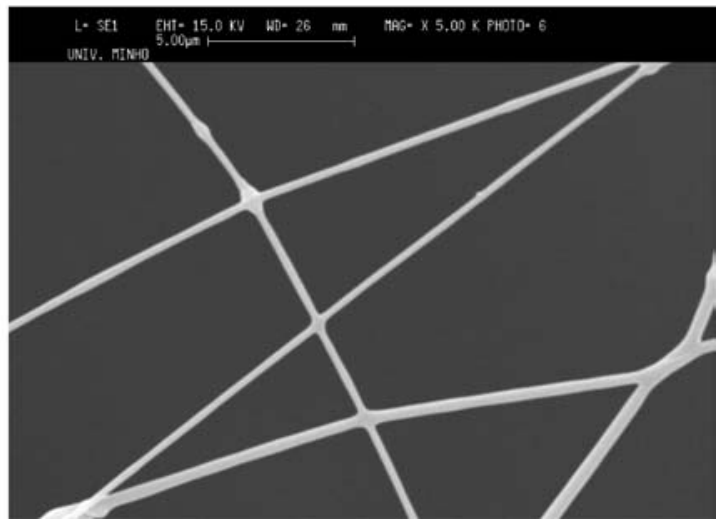

Figure 1 Microscopic images of the scaffolds. (B) presents a detailed view of nanofibers as observed by SEM.

\subsection{Cell culture}

\subsubsection{Morphological Analysis}

Regarding cell culture studies with SaOs-2 and RBMSC, cell responses in both cases were clearly different to the nano/micro fiber combined scaffolds when directly compared with the control fiber mesh scaffolds. It was observed that there were significant differences, mainly those related with cell shape and morphology, which could indicate that the patterned layered by the nanofibers was leading to a different cytoskeleton rearrangement on the seeded cells. SEM images showed that cells had covered microfibers and started to fill the spaces between the latter using for that purpose the previously laid down nanofibers after 7 days of culture. Fig. 2 shows confluent growth on combined scaffolds and control by the SaOs-2 osteoblast-like cell line. As it can be observed the cell population growing on the combined scaffolds presented a different organization being able to bridge between microfibers. The presence of nanofibers also led to the changes in cell morphology (Fig. 2(c) and (d)). Cells along the nanofibers showed very stretched morhologhy. This fact can be particular useful as this cytoskeletal rearrangement could affect gene expression, as described by a report of Curtis and Wilkonson [21]. It has been claimed that when the cells stretch themselves, the receptors are also stretched and activated. This results on the expression of different genes than those observed in unstretched cells. This particular hypothesis will be further confirmed in forthcoming (already ongoing) studies. A similar cell response was observed in the study with RBMSC (Fig. 3). After 14 days of culture, the scaffolds were covered by cells which used nanofibers to bridge between microfibers (Fig. 3(b) and (c)). 
A)

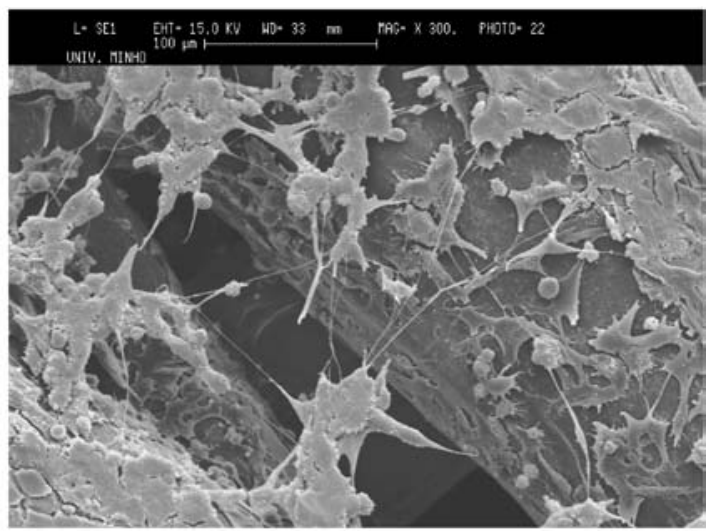

B)

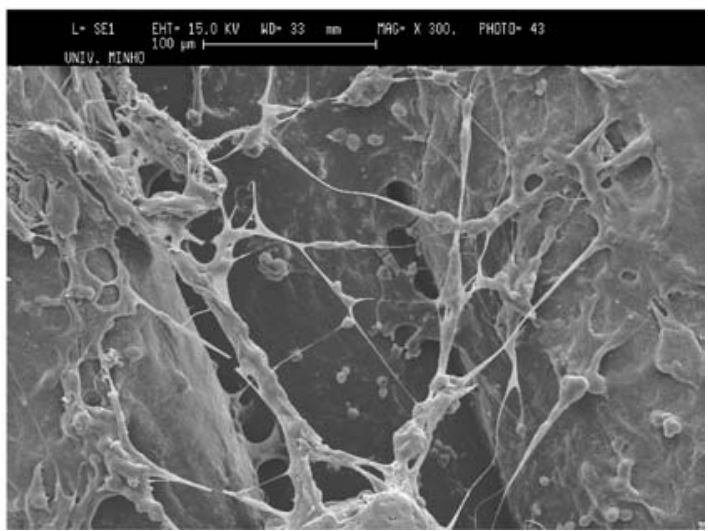

C)

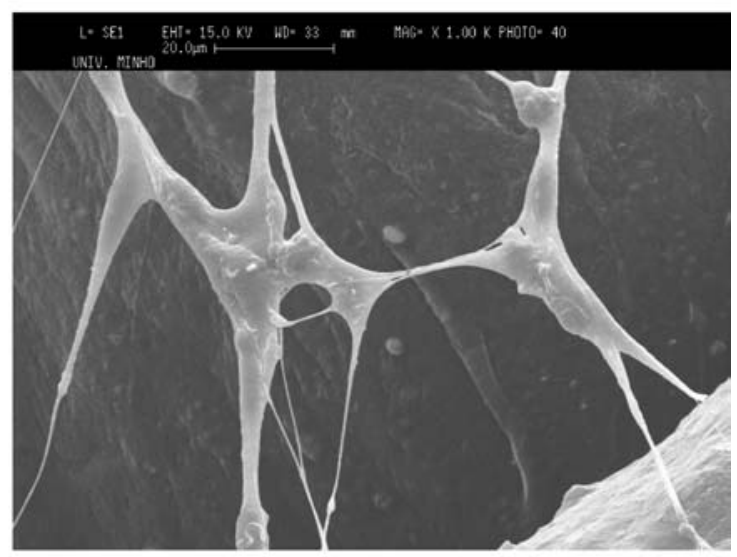

D)

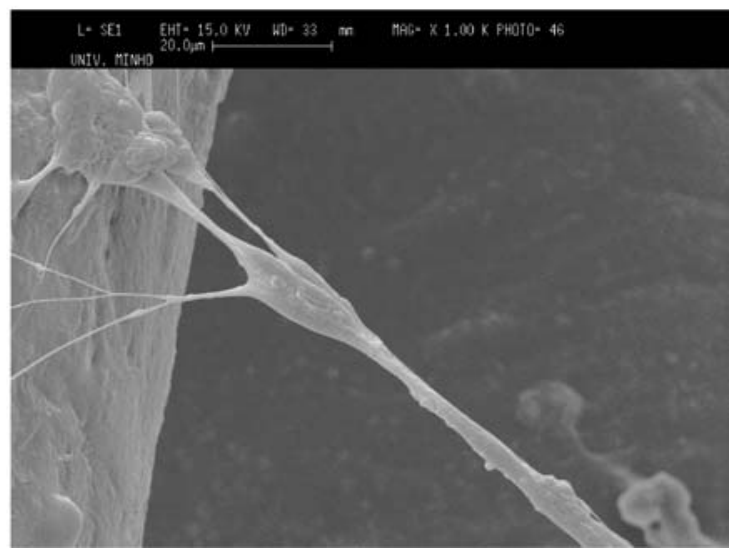

Figure 2 Human osteoblast like cells (SAOS-2) seeded on nanoand micro-fiber combined scaffolds and control (scaffolds without nanofibers); (A) after 7 days, (B), (C) and (D) after 14 days of culture.E) Human osteoblast like cells on control scaffolds after 14 days of culture. (Continued)
E)

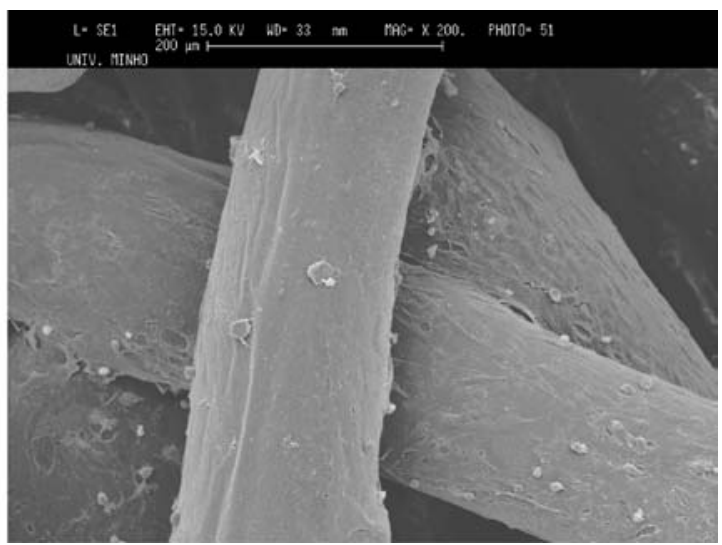

Figure 2 (Continued)

It is known that human cells can attach and organize themselves well around the fibers diameter smaller than those of the cells [22]. This approach might explain the behavior of the cells on the developed combined scaffolds. This cell organization could provide better and faster colonization of the scaffolds with cells which is of main importance for tissue engineering approaches.

\subsubsection{Cell viability}

The effect of nano/micro fiber combination on cell viability and proliferation of both cell types was tested using a MTS assay. The MTS assay is based on a reduction reaction which reduced MTS reagent to brown formazan product when incubated with viable cells. Thus, the absorbance of formazan indirectly reflected the metabolic activity of cells, which is also associated with cell number. Figs. 4 and 5 present the MTS results of cell culture studies with SAOS-2 and BMSC, respectively. After 7 and 14 days of culturing O.D. values were found to be considerably different for combined scaffolds in both studies. These results indicate that both cell types seeded on combined scaffolds showed increasing metabolic activity and growth rates when directly compared with the control. This fact is closely related with the previously deposited nanofiber mesh. While reducing large void spaces between the pores the mesh is creating additional structures where cells can adhere from the very beginning, avoiding at the same time that the cell suspension drops through the pores until it reaches the bottom of the wells. This particular phenomena shows the validity of the proposed methodology for increasing the cell seeding and culturing conditions during the development of bone tissue engineered constructs.

\subsubsection{ALP activity}

ALP is a well-known enzyme used as a marker of the osteogenic phenotype, which catalyzes the hydrolysis of phosphate esters at an alkaline $\mathrm{pH}$ [23]. The skeletal isoform of ALP is a glycoprotein found on the cell membrane of osteoblasts [24]. It has been also demonstrated that it plays an important role in bone matrix mineralization process. 
A)

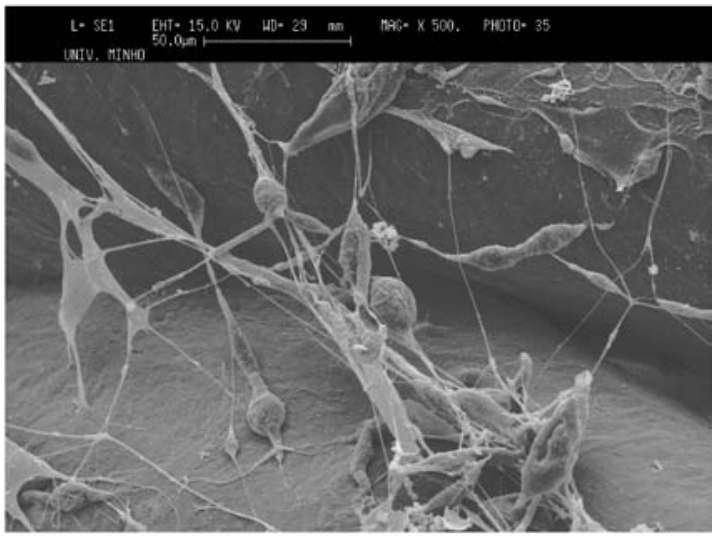

B)

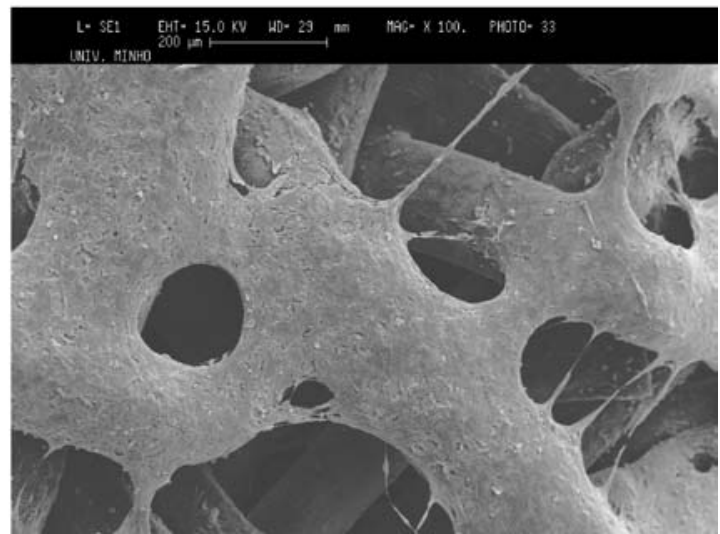

C)

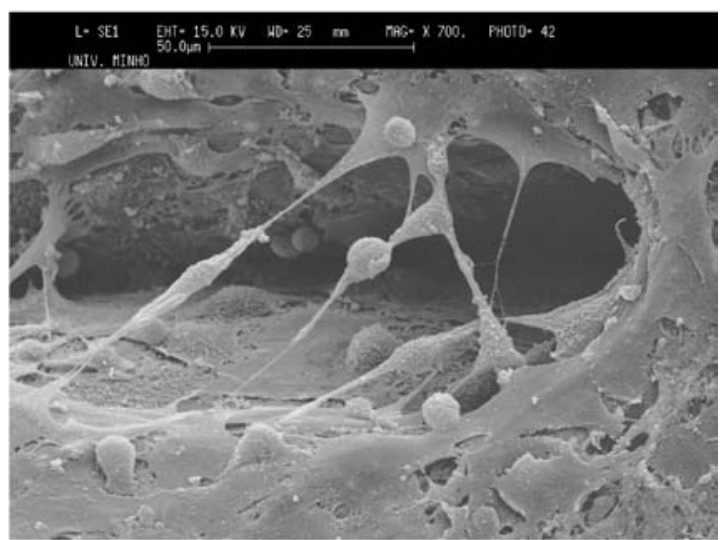

D)

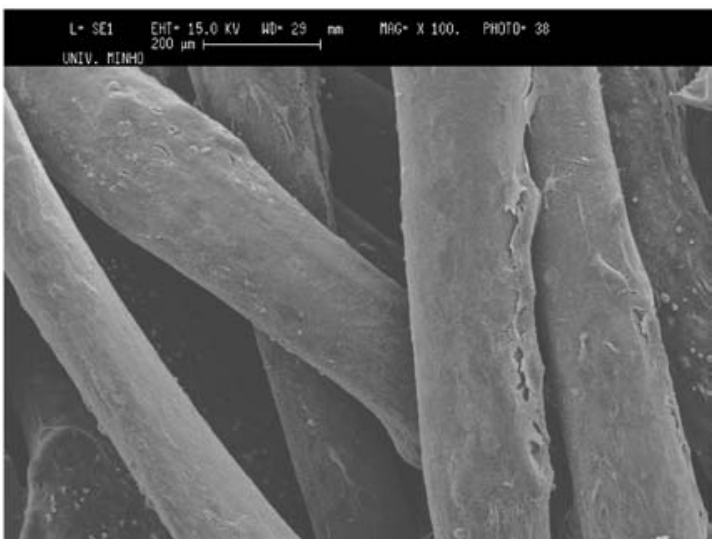

Figure 3 Rat bone marrow stromal cells (RBMSC) seeded on nanoand micro-fiber combined scaffolds and control (scaffolds without nanofibers); (A) after 7 days, (B) and (C) after 14 days of culture. (D) Rat bone marrow stromal cells on control scaffolds after 7 days of culture.

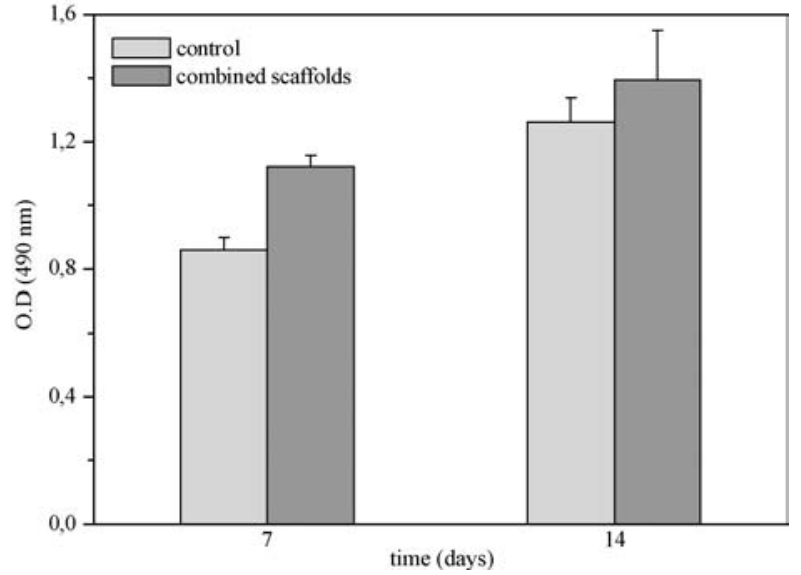

Figure 4 Cell viability and proliferation of human osteoblast like cells determined by MTS. Error bars represent means \pm SD for $n=3$.

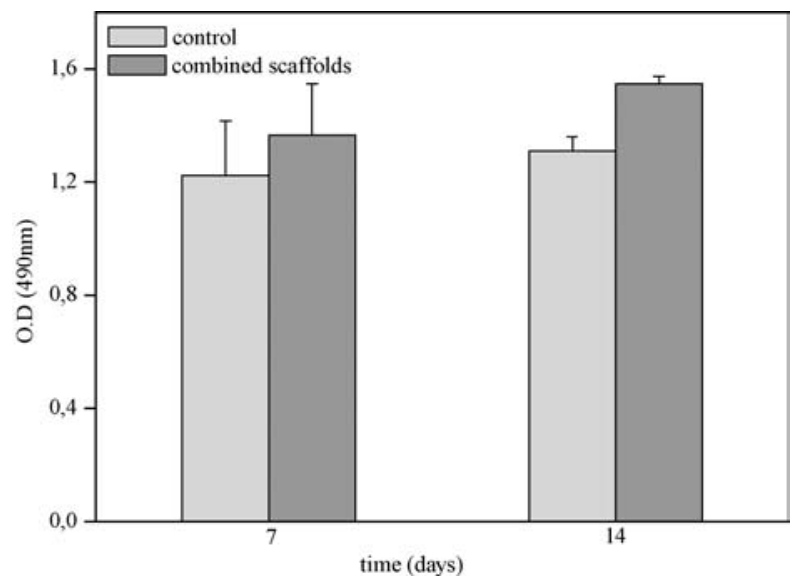

Figure 5 Cell viability and proliferation of rat bone marrow stromal cells determined by MTS. Error bars represent means \pm SD for $n=3$.

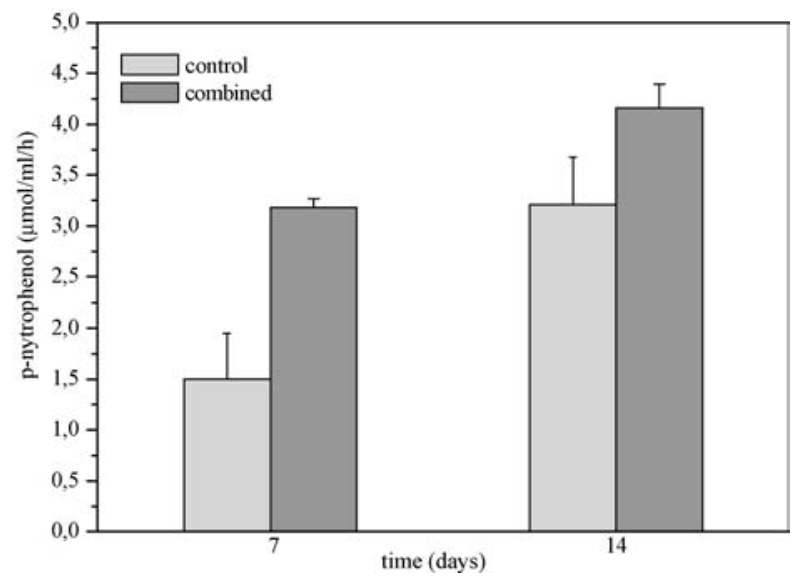

Figure 6 The ALP activity of human osteoblast like cells seeded on SPCL nano- and micro-fiber combined scaffolds and control (scaffolds without nanofibers). Error bars represent means \pm SD for $n=3$.

Figs. 6 and 7 shows the ALP activity of SaOs-2 and RBMSC cultured on the combined scaffolds and control scaffolds. In both cases, the enzyme activity of scaffolds with nano fibers was higher than that of control in the end of first week. In the case of RBMSC, the differences in enzyme activity became even higher 


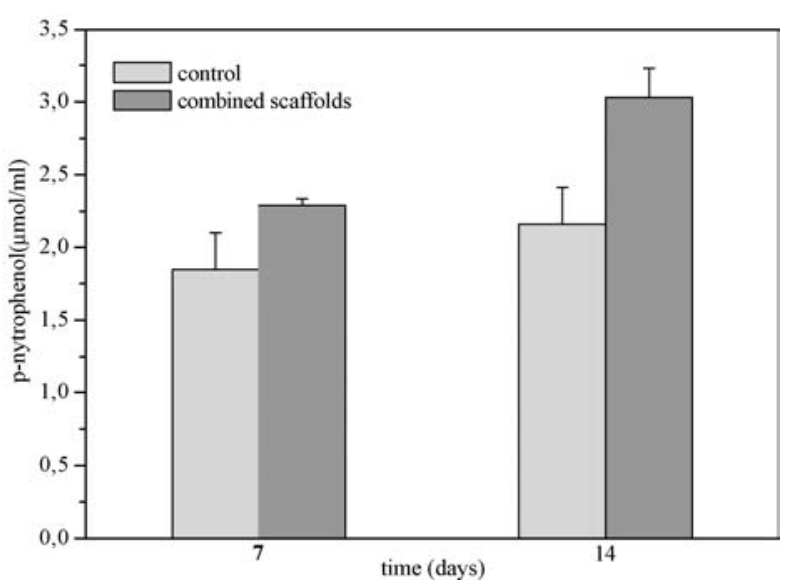

Figure 7 The ALP activity of rat bone marrow stromal cells seeded on SPCL nano- and micro-fiber combined scaffolds and control (scaffolds without nanofibers). Error bars represent means \pm SD for $n=3$.

after a second week of culture. This is probably related with the different proliferation rates of the cells seeded on the different scaffolds and at the same time with a probable more induced osteogenic phenotype. The latter hypothesis might be related with the cytoskeleton rearrengment caused by the nanofibers. However further studies are needed to evaluate the influence of these structures on the differentiation of osteogenic celss.

\section{Conclusions}

An electrospinning technique was used to produce nanofibers on SPCL fiber meshes in order to combine nano- and microfibers in the same 3D scaffold architecture. It was clearly demonstrated that cell response changed completely with the addition of nanofibers on the fiber meshes. Osteoblasts were organized to bridge between microfibers and this resulted in scaffolds completely filled with cells after two weeks of culture. Moreover, the presence of nanofibers had an influence in cell morphology which was observed to be much more streched and spread. The scaffolds without nanofibers did not show this kind of organization and the morphology of cells remained normal, and forming a continuous cell monolayer over microfibers. Furthermore, cells seeeded on combined scaffolds showed higher viability and ALP activity than that on control.

The results from this study indicate that nano- and micro-fiber scaffolds can provide an ideal structure for cell deposition and organization. Their unique architecture which supports and guides the cells makes them a suitable candidate for bone tissue engineering applications

\section{Acknowledgments}

K. Tuzlakoglu thanks the Portuguese Foundation for Science and Technology for providing her a $\mathrm{PhD}$ scholarship (SFRH/BD/8502/2002). This work was partially supported by FCT Foundation for Science and Technology, through funds from the POCTI and/or FEDER programmes and by the European Union funded STREP Project HIPPOCRATES (NMP3-CT2003-505758). This work was carried out under the scope of the European NoE EXPERTISSUES (NMP3CT-2004-500283).

\section{References}

1. M. E. GOMES and R. L. REIS, Macromol. Biosci. 4 (2004) 737.

2. X. LIU and P. X. MA, Annals of Biomedical Eng. 32 (2004) 477.

3. M. P. Lutolf and J. A. HuBbell, Nat. Biotechol. 23 (2005) 47.

4. Z. M. HUANG, Y. Z. ZHANG, M. KOTAKI and S. RAMAKRISHNA, Composites Sci. and Technology 63 (2003) 2223

5. D. LI and Y. XIA, Advanced Mater. 16 (2004) 1151.

6. J. A. MATtheWS, G. E. WNEK, D. G. SiMPSON and G. L. B OWLIN, Biomacromolecules 3 (2002) 232.

7. K. OHKAWA, D. CHA, H. KIM, A. NISHIDA and H. YAMAмото, Macromol. Rapid Commun. 25 (2004) 1600.

8. B. MIN, S. W. LEE, J. N. LIM, Y. YOU, T. S. LEE, P. H. KANG and W. H. PAR K, Polymer 45 (2004) 7137.

9. H. J. JIN, S. V. FRIDRIKH, G. C. RUTLEDGE and D. L. KA PLAN, Biomacromolecules 3 (2002) 1233.

10. W. K. SON, J. H. YOUK, T. S. LEE and W. H. PARK, Polymer 45 (2004) 2959.

11. W. Li, C. T. LAURENCIN, E. J. CATERSON, R. S. TUAN and F. K. KO, J. Biomed. Mater. Res. 60 (2002) 613.

12. F. YANG, R. MURUGAN, S. WANG and S. RAMA KRIS HNA, Biomaterials 26 (2005) 2603.

13. H. YOSHIMOTO, Y. M. SHIN, H. TERAi and J.P. VACANTI, ibid. 24 (2003) 2077.

14. W. Li, K. G. DANIELSON, P. G. ALEXANDER and R. S. TUAN, J. Biomed. Mater. Res. Part A 67A (2003) 1105.

15. S. KIDOAKI, I. K. KWON and T. MATSUDA, Biomaterials 26 (2005) 37.

16. W. LI, R. TULI, X. HUANG, P. LAQUERRIERE and R. S. TUAN, ibid. 26 (2005) 5158.

17. H. JIN, J. CHEN, V. KARAGEORGIOU, G. H. ALTMAN and D. KAPLAN, ibid. 25 (2004) 1039.

18. M. E. GOMES, R. L. REIS and A. M. CUNHA, Mater. Sci. Eng. C: Biomimet. Supramolec. Syst. 20 (2002) 19.

19. M. E. GOMES, V. I. SIKAVITSAS, E. BEHRAVESH, R. L. REIS and A. G. MIKOS, J. Biomed. Mater. Res. Part A 67A (2003) 87.

20. F. ROSSO, A. GIORDANO, M. BARBARISI and A. B ARB ARIS I, J. Cellul. Phys. 199 (2004) 174.

21. A. CURTIS and C. WILKINSON, Biomaterials 18 (1997) 1573.

22. C. T. Laurencin, A. M. A. Ambrosio, M. D. BORDEN and J. A. COOPER, Annu. Rev. Biomed. Eng. 1 (1999) 46.

23. H. HARR IS, Clinica Chimica Acta 186 (1989) 133.

24. T. STIGBRAND "Present Status and Future Trends of Human Alkaline Phosphatases. Human Alkaline Phosphatases." (Alan R. Liss, New York, 1984) p.3.

Received 30 June

and accepted 23 August 2005 